\title{
Assimilation of the Muslim communities in the first decade of the Turkish Republic (1923-1934)
}

Erol Ülker

\section{(2) OpenEdition}

Journals

Édition électronique

URL : http://journals.openedition.org/ejts/822

DOI : $10.4000 /$ ejts. 822

ISSN : 1773-0546

Éditeur

EJTS

Référence électronique

Erol Ülker, «Assimilation of the Muslim communities in the first decade of the Turkish Republic

(1923-1934) », European Journal of Turkish Studies [En ligne], Liste complète, mis en ligne le 11 janvier

2008, consulté le 19 février 2020. URL : http://journals.openedition.org/ejts/822 ; DOI : 10.4000/ejts.

822

(c) Some rights reserved / Creative Commons license 


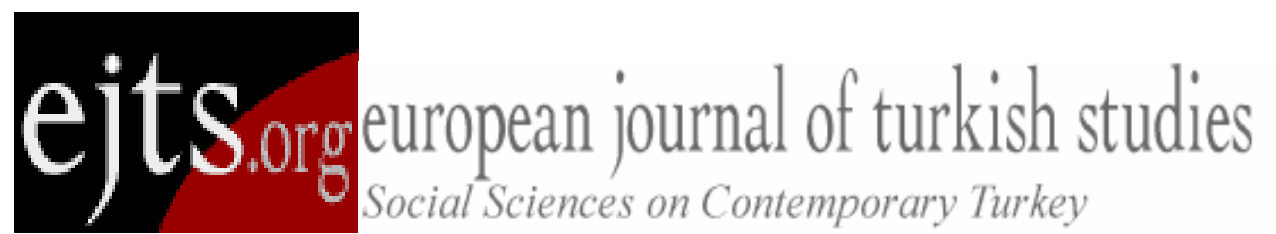

Citation: Ülker, Erol 'Assimilation of the Muslim communities in the first decade of the Turkish Republic (1923-1934)', European Journal of Turkidh Studies, URL: http://www.ejts.org/document822.html

To quote a passage, use paragraph $(\S)$.

\title{
Assimilation of the Muslim communities in the first decade of the Turkish Republic (1923-1934) \\ Erol Ülker
}

\begin{abstract}
The aim of this paper is to demonstrate how immigrationsettlement policies were employed by post-Lausanne Turkey to create a homogenous nation-state. Focusing on the incorporation of immigrants in the period of 1923-1934, the paper argues that the state policies of migration and settlement pursued two primary objectives that were closely connected with the nationalizing measures. They were carried out for the assimilation of non-Turkish-speaking Muslims on the one hand, and for the Turkification of Kurdish-populated eastern provinces on the other.
\end{abstract}


Citation: Ülker, Erol 'Assimilation of the Muslim communities in the first decade of the Turkish Republic (1923-1934) ', European Journal of Turkish Studies, URL: http://www.ejts.org/document822.html

To quote a passage, use paragraph (§).

Forced migration became one of the major instruments for the homogenization of the population in the late Ottoman Empire, and the interwar Turkey. After the compulsory exchange of minority populations with Greece, the population was far more homogeneous in terms of religious composition (Toprak 1998: 1-2). The deportation of Armenian population in 1915 under the rule of Committee of Union and Progress (CUP) and the mass exodus of Greek population during and after the War of Independence had been earlier catastrophic developments in this respect (Akçam 1997, McCarty 1998: 335-345).

[2] Yet the relevance of population movements for the goals of nation-building was not confined to the policy of expulsion exercised upon the non-Muslim populace. Migration became central to the nationalization policies of Turkey not only as a refugee producing process but also as a refugee incorporation device, which concerned overwhelmingly the question of how to unify the ethnically, culturally and linguistically diversified Muslim population of post-Lausanne Turkey ${ }^{1}$. I aim to demonstrate in this paper that during the interwar period, migration and settlement policies were carried out for two goals that were closely connected with the nationalizing policies targeting the nonTurkish speaking Muslims. The first goal was the assimilation of Muslim immigrants. By settling them among Turkish speaking population of Anatolia, the ruling elite of the republican Turkey aimed to assimilate non-Turkish speaking Muslim immigrants on the basis of Turkish language and culture. The second objective, on the other hand, was the settlement of new immigrants - who were considered as Turkish due to cultural and linguistic affinities - into the Kurdish-populated areas with the aim of changing the demographic structure there in favor of Turkish population.

[3] I examine the period that starts with the establishment of the new Republic and ends with the promulgation of a crucial law of settlement on June 14, 1934². Dividing the country into three zones of settlement according to the degree of concentration of the Turkish population, this law was designed to 'create a country speaking with one language, thinking in the same way and sharing the same sentiment...' ${ }^{\prime 3}$. Among the regulations and laws that were issued during the interwar period, this law is the most striking one in manifesting the assimilative mentality of the government.

\footnotetext{
${ }^{1}$ For the existing studies over similar theme, see Kirişçi (2000), Çağaptay( 2002).

2 'İskan Kanunu', no: 2510, 14/06/1934, Düstur, Tertip: 3, Cilt: 15, pp. 1156-1175.

3 TBMM Zabıt Ceridesi, Devre: IV, Cilt: 23, İçtima: 3, 14/06/1934, p. 141.
} 
Citation: Ülker, Erol 'Assimilation of the Muslim communities in the first decade of the Turkish Republic (1923-1934) ', European Journal of Turkish Studies, URL: http://www.ejts.org/document822.html

To quote a passage, use paragraph (§).

[4] This periodization is not coincidental. I aim to demonstrate that the law of 1934 did not formulate the assimilative design of settlement policies for the first time. Rather, its function was to combine the forerunning practices of settlement-immigration designed earlier by the various pieces of official regulations under the same legislation. These earlier legislations were built on the attempt of constructing a culturally and linguistically homogenous nation, a device of nation building which came onto the agenda of governmental policies long before the settlement law of 1934 .

[5] This is to say that the use of settlement-immigration policies for assimilatory purposes was not unique to the 1930s. Fuat Dündar provided an extensive documentation of how the Turkification policies conducted by the Young Turk rule after the Balkan Wars targeted not only Greek and Armenian communities of the late Ottoman Empire but also non-Turkish speaking Muslims such as Bosniaks, Albanians, Kurds and Arabs (Dündar 1999). Making an extensive use of Dündar's work, I have also discussed elsewhere that the different ethnic and linguistic groups were subject to different settlement policies after the Balkan Wars (Ülker 2005).

[6] This is by no means to say that nothing changed from the Young Turks period to the Republic in terms of the settlement-immigration policies. Nor is it to claim that the dynamics of assimilation or, more broadly, Turkification policies were the same under the Young Turk regime and the Republic. Discussing the changing dynamics of Turkification and the relevance of the settlementimmigration policies to these dynamics in the imperial and the republican contexts is a subject of an independent article. Such an attempt must not only deal with the changing dynamics of Turkification but also question if this very term is a sufficient concept to define altogether a number of separate, if not independent, policies such as geographical nationalization, assimilation and dissimilation.

[7] Suffice it to underline in this article that the ruling elite of the young Republic was quite familiar with how to put the settlement-immigration policies into the service of homogenizing the population. The Young Turk rule considered the settlement of Muslim immigrants as an important tool of social engineering. They were settled throughout Anatolia in order to increase the number of Muslims in regions where non-Muslim groups constituted the majority. While deporting the nonMuslims, the government tried to settle the Muslim immigrants in their stead (Dündar 1999: 65).

[8] At the same time, the CUP government did not consider the Muslim immigrants as a homogenous group of people. Rising Turkish nationalism during its rule went hand in hand with the 
Citation: Ülker, Erol 'Assimilation of the Muslim communities in the first decade of the Turkish Republic (1923-1934) ', European Journal of Turkish Studies, URL: http://www.ejts.org/document822.html

To quote a passage, use paragraph (§).

increasing sensitivity to the ethnic, religious and linguistic peculiarities of the subject population. One of the goals of the settlement policies was to promote the assimilation of immigrant communities into Turkish culture on the one hand, and not to allow the clustering of the same ethnic group in the same region on the other (Ülker 2005: 626-629). In locating Albanian immigrants, for example, the government was intent on settling them in regions far away from the Balkans. Çatalca, Edirne, İstanbul, İzmir and Karesi, were closed to the settlement of Albanian immigrants (Dündar 1999: 114). Similar measures were undertaken for the settlement of Bosnian immigrants. There was no regional restriction for Bosnians' settlement but promoting their assimilation in Turkish culture was one the major concerns of the government in locating them (Dündar 1999: 124). For both the settlement of Albanian and Bosnian immigrants, the government applied to a condition according to which, in a region, the total number of the immigrants should be below ten per cent of the total Turkish inhabitants (Ağanoğlu 2001: 117).

[9] I show below that the government of the young Republic drew on the policies that had been developed earlier by the CUP rule. This continuity in the application of immigration-settlement policies in the first decade of the Republic has actually broader connotations for the analysis of Turkish nationalism in the interwar period. It questions an established view running through the large body of scholarship about Turkish nationalism. There is almost a consensus that the 1930s was a period in which Turkish nationalism was imbued gradually more with an ethnic formulation of Turkishness. In this respect, a significant difference is pointed out between the 1920s and the 1930s in terms of the formulation of Turkishness. Of importance to this article, the aggressive wording of the settlement law of 1934, which makes open ethnic references to Turkishness, is indicated as the result of the growing emphasis on ethnicity.

[10] There is no way to refuse the genuine shift towards more ethnic formulation of Turkishness in the political discourse during the second decade of the Republic. Nor is it possible to overlook the aggressive discourse of the settlement law of the 1934. Yet if we step out of the sphere of discourse and look at the actual state policies, the distinction made between the 1920s and the 1930s gets blurred. I demonstrate below that before the promulgation of the law of 1934, the government had already set in motion an assimilatory mentality in the settlement policies. This means that the actual state practices with respect to settlement-immigration policies did not differ fundamentally from the 1920s to the 1930s as far as the assimilation of the Muslim population was 
Citation: Ülker, Erol 'Assimilation of the Muslim communities in the first decade of the Turkish Republic (1923-1934) ', European Journal of Turkish Studies, URL: http://www.ejts.org/document822.html

To quote a passage, use paragraph (§).

concerned. One cannot find significant differences in these two periods at the level of settlement policies in the sense of the classification of the population according to the cultural and linguistic features identified with dominant Turkish population.

[11] In what follows, I deal first with the influx of the immigrants to the country with special attention to the promotion of immigrations from the Balkans. Subsequently, the assimilatory measures of settlement are demonstrated. Consideration is given not only to the laws and regulations of settlement but also to their implementation as far as the available documents allow.

[12] Before proceeding any further, however, it should be acknowledged that this research leaves out a set of crucial aspects of settlement-immigration policies because of a lack of sufficient data. First and foremost, unless otherwise stated, we are not able to follow in most cases whether the official decisions and measures were actually implemented. Although this is admittedly a serious problem given the material weakness of the young Republic, I believe we can still come to significant conclusions about what was intended more than what was practiced on the basis of available data. Secondly, this article aims to display the state perspective on immigration-settlement rather than that of immigrant communities. It takes a fundamentally different sociological study to investigate the reaction of the immigrant communities to the state-initiated policies, which is beyond the concerns of this study. Thirdly, despite its significance, I exclude from my analysis the negotiations between the immigrants and the state, which must have had grave importance on the actual practices of settlement. Being concerned with the state mentality of assimilation, I deliberately choose to focus on what was meant by the official policies of settlement-immigration.

\section{Promotion of Immigrations}

[13] The period from 1923 to 1939 witnessed state-generated influx of immigrants especially from the Balkan countries. Around 800,000 people entered Turkey as immigrant in these years ${ }^{4}$. Significant number of them came from Greece under the framework of population exchange implemented after 1923. According to Geray (1962: 11), the number of Muslim immigrants of Greece origin was 384,000 , which constituted 61.1 per cent of the total number of immigrants between 1923

\footnotetext{
${ }^{4}$ According to Cevat Geray (1962: 7), the number of immigrants were 823,006 in this period. Kemal Kirişçi (2000: 8) estimates the same figure as 825,022 and Gülten Kazgan (1983: 1556) as 801,808.
} 
Citation: Ülker, Erol 'Assimilation of the Muslim communities in the first decade of the Turkish Republic (1923-1934) ', European Journal of Turkish Studies, URL: http://www.ejts.org/document822.html

To quote a passage, use paragraph (§).

and $1933^{5}$. During the years under consideration, 198,688 migrants moved to Turkey from Bulgaria according to figure provided by both Kemal Kirişçi (2000: 8) and Halit Eren (1993: 294). Besides, 117,095 people coming from Romania entered Turkey during the same period. An interesting fact is that the vast proportion of migration movement from Romania to Turkey occurred after 1933. Between 1923 and 1933, only 33,852 people left Romania for Turkey (Geray 1962: 11). Finally, 115,210 people from Yugoslavia moved to Turkey during the years between 1923 and 1939 (Kirişçi 2000: 8). In contrast to Romania, the vast majority of immigrants from Yugoslavia, which accounts for 108,709, came between 1923 and 1933 (Geray 1962: 11) ${ }^{6}$.

[14] What is to be noted at this point is that the government promoted immigrations to the country during the interwar period. In 1928, for example, USA's Turkish Embassy reported the Turkish propaganda in Romania to the Secretary of State. This report claimed that numerous MuslimTurks in the Romanian Dobrudja responded to Turkish propaganda and migrated to their new homes in Anatolia. The same report points to the existence of similar propaganda in Bulgaria. It was claimed that considerable number of Turks from Bulgaria was moving to Turkey and that further propaganda to increase such emigration was being carried out ${ }^{7}$.

\footnotetext{
${ }^{5}$ Both Kiriş̧i and Geray estimate the immigrants of Greece origin who migrated to Turkey because of compulsory exchange of population as 384,000 . However, another important resource concerning the immigrations puts the same number as 499,239 (İskan Tarihçesi 1932: 137). Therefore, we can estimate that the total number of immigrants between 1923-1939 can be higher than what Kirişci and Geray estimate.

${ }^{6}$ Although the overwhelming majority of officially reported immigrants came from the Balkan Peninsula, there were some other immigration movements from Caucasus, Cyprus and Syria. In December 1925, for example, a governmental decree concerning the settlement of approximately 20,000 Muslim immigrants from Cyprus was published: 'KIbristan Gelecek Muhacirlerin İskanlarına Tahsis Olunan Arazi Hakkında Kannunname', no: 1118, 7/12/1341-7/12/1925, Düstur, Tertip: 3 , Cilt: 7: 130. On June 27, 1927, the Turkish Press announced that approximately 15,000 immigrants from Syria, 10,000 from Cyprus and 50,000 from Caucasus would enter Turkey 'Muhacir Celbi' (Milliyet, 27 June 1927: 3). It was asserted that about 50,000 immigrants would leave Soviet Union for Turkey in accordance with the Moscow and Kars Treaties (Milliyet, 10 June 1927: 2). There were immigrations from Georgia as well. Some of the Muslim immigrants of Georgian origin arrived at Samsun 'Yeni Muhacirler' (Milliyet, 15 June 1927: 3) and some others were settled in Malatya (BCA, Fon No: 272.0.0.12, Yer No: 55.139..20,13/11/1927). Besides, according to an official report, Turkish population residing in Yemen longed for migrating to Turkey (BCA, Fon No: 272.0.0..12, Yer No: 45.75..22, 20/7/1925). There were immigrations even from Finland and Jordan (Çağatay, 2002a: 223). Migrations from the regions other than Balkan countries continued during the 1930s. In November 1934, for example, Şükrü Kaya, Minister of the Interior, informed the Grand National Assembly about the number of repatriates of Turkish origin. He stated that 15,319 Muslim Turks came to Turkey from June 1, 1933 to June 1, 1934. This number consisted of 4,284 persons from Russia, 325 from Syria, 1,112 from Persia and 252 from Dodocenase Islands in addition to the total of 9,476 persons from Bulgaria, Yugoslavia, Romania and the Western Thrace (BCA, Fon No: 272.0.0..12, Yer No: 55.139..27, 19/11/1927).
}

${ }^{7}$ Records of the Department of State Relating to the Internal Affairs of Turkey 1910-1929 (M 353), from Charles C. Wilson to the Secretary of State, 8/02/1928, 867.5574/1. 
Citation: Ülker, Erol 'Assimilation of the Muslim communities in the first decade of the Turkish Republic (1923-1934) ', European Journal of Turkish Studies, URL: http://www.ejts.org/document822.html

To quote a passage, use paragraph (§).

[15] Two significant themes imprinted their marks onto Turkey's immigration policy and brought about the promotion of the immigration flows. First, Anatolia was dramatically depopulated due to the war conditions before the construction of the new Republic. Hence, nationalist elite viewed the influx of immigrants to the country as one of the ways to increase the population. Hamdullah Suphi, a prominent figure of Turkish nationalism, expressed this consideration clearly in the discussions held in Turkish Parliament: 'I wonder if those who saw the empty spaces in Anatolia do not agree with the necessity to bring two-two and a half million more Turks to Anatolia ${ }^{18}$. He held that bringing the Muslim-Turkish communities inhabiting various corners of the Balkans and settling them in Anatolia was an urgent necessity to solve the demographic problems of Turkey.

[16] Secondly, as aptly observed by Tanıl Bora (1995: 35-36), the consideration of bringing the remaining Muslim-Turkish communities of the Balkans became a nationalist motto that was repeated by nationalist intelligentsia up to the end of the 1930s. The influx of immigrants to Anatolia was conceived as a factor strengthening the cohesion and homogeneity of Turkish nation. They were viewed as loyal members of the nation who shared the historical, cultural heritage of the Ottoman Empire. Şükrü Kaya, the Minister of Internal Affairs, stated this consideration concerning the population exchange as follows:

'The primary debt of a nation, the highest duty of a government is to assure the unity of a nation within its country. The basis of the convention of population exchange implemented in Lausanne is related with this object and formed for this object'?.

[17] He added in the same speech that 'Thanks to Lausanne Treaty, we added 500,000 people out of the strongest elements of our race to our country' ${ }^{10}$. He conceived the immigration of Greece's Muslims to Turkey as a development reinforcing the cohesion of Turkish nation. In fact, this consideration was not limited to the Muslims of Greece. It was believed that, apart from those who were not aware of their Turkishness, there were millions of Turks residing in Serbia, Bulgaria, Romania and Crimea. Bringing them to Anatolia was a 'national ideal' as early as $1923^{11}$.

\footnotetext{
8 TBMM Zabıt Ceridesi, Devre: II, Cilt: 11, İçtima: 19, 10/12/1340-10/12/1924, p. 15.

9 TBMM Zabıt Ceridesi, Devre: III, Cilt: 26, Içtima: 36, 19/03/1931, p. 60.

10 TBMM Zabıt Ceridesi, Devre: III, Cilt: 26, İçtima: 36, 19/03/1931, p. 62.

11 TBMM Zabıt Ceridesi, Devre: II, Cilt: 2, İçtima: 35, 13/10/1339-13/10/1923, p. 628.
} 
Citation: Ülker, Erol 'Assimilation of the Muslim communities in the first decade of the Turkish Republic (1923-1934) ', European Journal of Turkish Studies, URL: http://www.ejts.org/document822.html

To quote a passage, use paragraph (§).

\section{Settlement Policies}

[18] In reality, however, many non-Turkish ethnic and linguistic Muslim groups entered the country alongside Muslim-Turkish communities. The number of people whose native or secondary language was Albanian increased from 21,774 to 40,647 between 1927 and 1935 according to the demographic censuses conducted in these years (Dündar 1999: 81). According to the census of 1935, there were 38,141 people speaking Bosnian (Dündar 1999: 84) and 41,041 people speaking Pomak language as mother tongue or secondary dialect (Dündar 1999: 121). It is unfortunately not possible to establish with accuracy through the official censuses what proportion of these people were the immigrants entering Turkey in the early years of the Republic. We can only estimate that the actual numbers might have been higher than what was provided by the official censuses. Yet the fierce parliamentary discussions I refer to below over the inability of the government in settling nonTurkish speaker immigrants to 'inappropriate' locations show us that there were a significant number of immigrants as such alongside those of Turkish-speakers.

[19] In fact, this was rooted in the immigration policies of the Republic, which conceived some non-Turkish Muslim communities from the Balkans as part of the common Ottoman heritage and 'Turkish culture'. Having been the first significant official text governing voluntary immigrations, the Law on Settlement adopted in May 31, 1926 (Law 885) ${ }^{12}$ is the most relevant reference point to prove this argument. The first article of this law charged Ministry of Internal Affairs with the tasks of admitting the immigrants and refugees to the country, and of determining their regions of settlement. The Article 2 of the Law on Settlement, on the other hand, revealed who cannot be admitted as immigrant or refugee. According to it:

'People who do not belong to Turkish culture, who are infected with syphilis, who are subject to leprosy and their families, who are imprisoned because of committing murder except political and military reasons, anarchists, spies, gypsies, and who are exiled outside of the country cannot be admitted'13.

[20] Apparently, this law linked the admission of immigrants and refugees to the condition of affinity with Turkish culture. However, who was to be considered within this category was not specified in this law. Indeed, aside from outside Muslim-Turk population, this category was referring

\footnotetext{
12 'İskan Kanunu', no: 885, 31/06/1926, Düstur, Tertip: 3, Cilt: 7, pp. 1441-1443.
}

13 Ibid., p. 1441. 
Citation: Ülker, Erol 'Assimilation of the Muslim communities in the first decade of the Turkish Republic (1923-1934) ', European Journal of Turkish Studies, URL: http://www.ejts.org/document822.html

To quote a passage, use paragraph (§).

to the non-Turk ethnic and linguistic groups, especially from the Balkans. Although this point was not cited in the original text of the Law on Settlement, another significant official text adopted in relation to this law makes the matter quite clear. This is 'the Memorandum of Settlement' issued in August 1 , $1926^{14}$. The last paragraph of the first article of this memorandum states that:

'Pomaks, Bosnians, Tatars are deemed as bounded to Turkish culture and the applications of Albanians, who came to Turkey before and were registered, with respect to the admission of their families are being granted ${ }^{15}$.

[21] Taken together, the Law on Settlement adopted in 1926 and Memorandum of Settlement issued in relation to this law reveal the ethnic and linguistic preference of Turkey in admitting someone as immigrant. Alongside the Muslim-Turk communities, Pomaks, Bosnians and Tatars were also to be admitted. Although we cannot make sure the degree to which the government was able to practice this memorandum in reality, it is clear that it did not promote the coming of further Albanians since they were not counted among the ethnic groups perceived as tied to Turkish culture. Albanian immigration was restricted with the families of those who had already migrated ${ }^{16}$. The immigration claims of Gypsies were also to be rejected.

[22] Once admitted, however, the groups that were categorized as people of Turkish culture were to be subject to settlement policies that had been designed to assimilate them. In other words, as will be shown below, they would be accepted as new citizens of the Republic alongside who were considered as Turk immigrants but then would become the target of the homogenization efforts of the State. On the other hand, the settlement of Turkish-speaking immigrants especially of Balkan origin constituted the other dimension of social engineering. They were located to regions that were sensitive according to the national security concerns, such as Thrace and Eastern Anatolia.

\footnotetext{
14 'İskana Ait Muhtıra', Tertip: 63, 01/08/1926 in Eski ve Yeni Toprak, İskan Hükümleri ve Uygulama Klavuzu, Naci Kökdemir (ed.), (Ankara 1952), pp. 192-208.

15 'Pomaklar, Boşnaklar, Tatarlar, Türk harsına dahil addedilmekte ve evvelce Türkiye'ye gelerek tescil edilmiş olan Arnavutların hariçte kalan ailelerinin kabulleri hakkındaki muraacatlari daisaf olunmaktadır'. Ibid., p. 193.

16 The fact that Albanians had established their own national-state by rising against the Ottoman Empire in 1912 can be considered as one of the reasons why the government was suspicious about their immigration.
} 
Citation: Ülker, Erol 'Assimilation of the Muslim communities in the first decade of the Turkish Republic (1923-1934) ', European Journal of Turkish Studies, URL: http://www.ejts.org/document822.html

To quote a passage, use paragraph (§).

\section{The Ministry of Exchange, Reconstruction and Settlement}

[23] Throughout the 1920s and 1930s, a significant number of official laws, decrees and regulations were issued concerning the settlement and re-settlement not only of the immigrants and the refugees but also of the nomadic tribes, and the rebellious groups inhabiting the Eastern Provinces. The new Republic should have accommodated the influx of immigrants, especially those from Greece, and the vast number of population remained homeless because of the devastating impacts of the wars. To cope with the troubles posed by the necessity of settling homeless people and immigrant groups, the Ministry of Exchange, Reconstruction and Settlement (Mübadele İmar ve İskan Vekaleti) was established on October 13, 1923 (Arı 2000: 28). It was charged with the tasks of rebuilding the areas devastated by wars, as well as the settlement of exchangees, immigrants, refugees, and the homeless people ${ }^{17}$. It was provided with sweeping powers to make decisions on questions concerning these matters and to use all state employees and the military, police authorities (Ladas 1932: 707).

[24] At the same time, the government did not refrain from developing a long-term perspective of settlement that was to be put into the service of nation-building policies. For the settlement of exchangees of Greece origin, one of the primary objectives was to distinguish Turkish and non-Turkish groups. Before the establishment of the Ministry, a special decree including stipulations about this matter was published on July 17, 1923, that is, 'The Governmental Decree Concerning the Transaction of an Instruction Arranged according to the Convention Acted with Greek Delegation in Lausanne in January $30,1923^{\prime 18}$.

[25] In the first place, Articles 17 and 18 of this decree linked the issue of the settlement to the condition of nationality ${ }^{19}$. The former article leaves the decision about the place for settlement to the Turkish exchangees as long as they could afford the required costs without any demand from the government. Nevertheless, according to the latter article, it was obligatory for non-Turks to settle in the regions assigned by the government, regardless of their material conditions.

17 'Mübadele İmar ve İskan Kanunu', no: 368, 8/11/1339-8/11/1923, Düstur, Tertip: 3, Cilt: 5, p. 407.

18 '30 Kanunisani 1923 Tarihinde Lozanda Yunan Murahhaslariyla Yapılan Mukavele Mucibince Tanzim Olunan Talimatnamenin Mer'iyete Vaz'। Hakkinda Kararname', no: 2600, 17/7/1339-17/7/1923, Düstur, Tertip: 4, Cilt: 3, pp. 135142.

19 Ibid., p. 138. 
Citation: Ülker, Erol 'Assimilation of the Muslim communities in the first decade of the Turkish Republic (1923-1934) ', European Journal of Turkish Studies, URL: http://www.ejts.org/document822.html

To quote a passage, use paragraph (§).

[26] On the other hand, Article 29 made the conditions for the settlement of the non-Turkish and non-Turkish-speaking immigrants clear.

'By taking into account that the most difficult obstacle to the civil and social improvement is the dissimilarity in the language and customs, the proportion of the immigrants, regardless of race or nationality, whose language and customs belong to another race shall never be over 20 percent in any Turkish town and village ${ }^{\prime 20}$.

[27] Professional and racial traits will be taken into consideration, in addition to the geographical and economical features of the places they immigrated from. It is apparent in these stipulations that the government aimed to settle the non-Turkish-speaking immigrants on the basis of the conditions that made their adaptation to Turkish culture and language as easy as possible. By limiting their proportion to $20 \%$ in Turkish towns and villages, it was intended to make their assimilation possible without posing any threat to the social order. However, we cannot make sure the extent to which these stipulations, including the restriction of $20 \%$, were actually practiced.

[28] In the discussions of the Turkish National Assembly on the adoption of a law concerning the establishment of the Ministry of Exchange, Reconstruction and Settlement, the assimilatory perspective was connected to the prevailing idea of creating a homogenous nation-state. Besim Atalay, an ardent Turkish nationalist, called attention to the dangers of settling individuals who possessed the language and customs of a different national group in an area. Likewise, Abidin (Daver) called the new Ministry to settle the immigrants by taking into account the necessity of their mixing with the 'original inhabitants' (sekene-i asliye) $)^{21}$.

[29] In the early years of the Republic, the government attempted to follow this mentality in settling immigrants. In particular, it was careful with Albanian and Bosnian immigrants and endeavored to settle them in a programmatic way. As early as August 4, 1923, the Turkish Grand National Assembly addressed a decree to most of the provinces of the country, inquiring about the

\footnotetext{
20 One point has to be clarified at this juncture. In all the official correspondences mentioned in this article, the term 'Türk' is used. I sometimes have to translate this term as Turkish for grammatical convenience. The terms Turkish and Turk are used interchangeably for 'Türk', unless otherwise stated. In this quotation, for example, 'Turkish town and village' stands for 'Türk kasaba ve köyünde'. In my own wording, I also use these terms interchangeably to refer to 'Türk' when I make reference to official correspondences to avoid repeating the same word. I would like to thank the anonymous reader for drawing my attention to possible confusions that would arise from the use of Turk and Turkish for the same category of 'Türk'. Ibid., p. 140.

21 TBMM Zabıt Ceridesi, Devre: II, Cilt: 3, İçtima: 48, 04/11/1339-04/11/1923, p. 216.
} 
Citation: Ülker, Erol 'Assimilation of the Muslim communities in the first decade of the Turkish Republic (1923-1934) ', European Journal of Turkish Studies, URL: http://www.ejts.org/document822.html

To quote a passage, use paragraph (§).

situation of Albanian and Bosnian immigrants ${ }^{22}$. This decree required information from the local authorities, pertaining to the number of immigrants within the boundaries of the provinces and locations in which they had been settled. It also asked for an estimate of the number of Albanian and Bosnian immigrants that the locations were able to receive. The responses of the local authorities attested to the importance of the settlements issue. For example, the government was informed that out of the 16 Albanian families from Kosova and Manastır, 10 families were settled in the Bor region and 6 families were settled in the center of Niğde district ${ }^{23}$. Another instruction issued by the Ministry is edifying in terms of the assimilative attitude of the government :

'It is decided to transfer 500 Albanian people who dwell in İzmir-Bornova to interior regions. It is requested urgently to be made known how many families could be settled in the province conditionally to the abandoned Armenian properties and in a scattered way ${ }^{24}$.

[30] This decree that was addressed to the local authorities of Niğde and Burdur provinces reveals important aspects of the Republic's settlement policies in its early years. On the one hand, the specific condition it provided illuminates the assimilative perspective of the settlement policies. The Ministry sought to prevent concentration in one region, which would make assimilation harder. On the other hand, this decree demonstrates another policy the Republic set in motion from its early years on. The settlement of non-Turkish immigrants to some areas, which were conceived as delicate regions according to the national security concerns, was viewed inappropriate. Aegean coasts, for instance, came to be one such delicate area in the face of the tensions with Greece and subsequently with Italy. In most cases, interior Anatolia was the ideal place to locate non-Turkish immigrants. On March 16, 1923, for example, another group of Albanian immigrants was transferred from İzmit to the interior provinces of Konya and Eskisehir ${ }^{25}$.

[31] We cannot figure from the aforementioned documents the period in which the immigrants referred to came to Anatolia. Yet it is for sure that Albanians and Bosnians were not the only groups of people whose settlement in regions such as Thrace, Eastern and Western Anatolia was prevented. Bulgarian-speaking Pomaks came to be treated in the same way. On March 17, 1924, for example,

\footnotetext{
${ }^{22}$ BCA, Fon No: 272..0.0.11, Yer No: 16.66..1, 04/08/1923.

${ }^{23} \mathrm{lbid}$.

${ }^{24}$ BCA, Fon No: 272..0.0.11, Yer No: 19.90..10, 11/06/1924.

25 BCA, Fon No: 272..0.0.11, Yer No: 16.65..1, 16/03/1923.
} 
Citation: Ülker, Erol 'Assimilation of the Muslim communities in the first decade of the Turkish Republic (1923-1934) ', European Journal of Turkish Studies, URL: http://www.ejts.org/document822.html

To quote a passage, use paragraph (§).

the Ministry issued a decree asking for information about the number and professions of the Pomaks whose settlement in Thrace was rejected ${ }^{26}$.

[32] In addition to the immigrants from the Balkans, similar measures were employed for the people of Caucasian origin in the early years of the Republic. For example, an instruction promulgated by the Ministry showed that a group of Circassian immigrants was transferred to Malatya and Niğde due to political concerns ${ }^{27}$. Although the political reasons that had led to their deportation were not overtly mentioned in this instruction, it reveals how the settlement practices were deployed by the Republic in line with the political measures. Another direction issued by the Ministry points to the attention given to the settlement of the Caucasian immigrants and illuminates the suspicious attitude of nationalist elite against them. This direction limited the settlement districts of Georgian and Azeri immigrants and it rejected of the immigration of White Russians ${ }^{28}$.

[33] The 'Law concerning the Immigrants, Refugees and Nomads who Change Their Settlements without Permission', published on November 30, 1925, illustrates the commitment of the government to the rules of settlement ${ }^{29}$. This law made it obligatory to inhabit for five years in the areas of settlement specified by the government. In fact, before the adoption of this law, the Ministry had already been concerned with this issue. For example, it was figured out that 44 exchangees from Drama, who had been settled in Samsun, went to İstanbul without permission. As a result, the Ministry ordered the transfer of these exchangees from İstanbul to Samsun with a directive issued on January $29,1924^{30}$. Furthermore, on March 6, 1924, it published a special instruction that ordered the settlement of the exchangees of Greece to the places assigned in the agreement ${ }^{31}$. Nevertheless, facing the increasing number of escapes, the government found it necessary to adopt a special law about this matter (Isskan Tarihçesi 1932: 65). By means of this law, it attempted to fix the places of immigrants where they had been settled.

[34] In effect, these official regulations were concerned especially with 'non-reliable elements'. For example, an instruction issued on May 11, 1925, ordered the transfer of a group of

\footnotetext{
${ }^{26} B C A$, Fon No: 272..0.0.11, Yer No: 17.79..6, 17/03/1924.

${ }^{27}$ BCA, Fon No: 272..0.0.11, Yer No: 18.96..9, 11/06/1924.

${ }^{28}$ BCA, Fon No: 30..18.1.1, Yer No: 9.27..8, 28/05/1924.

29 'Mahalli İskanlarını Bila Mezuniyet Tebdil Eyleyen Muhacir ve Mültecilerle Aşair Hakkında Kanun', no: 675, 30/11/1341-

30/11/1925 in Eski ve Yeni Toprak, İskan Hükümleri ve Uygulama Klavuzu, pp. 18-19.

${ }^{30}$ BCA, Fon No: 272..0.0.11, Yer No: 17.44..77, 29/01/1924.

31 BCA, Fon No: 272..0.0.11, Yer No: 17.81..6, 06/03/1924.
} 
Citation: Ülker, Erol 'Assimilation of the Muslim communities in the first decade of the Turkish Republic (1923-1934) ', European Journal of Turkish Studies, URL: http://www.ejts.org/document822.html

To quote a passage, use paragraph (§).

exchangees who had left the areas of Çanakkale and Bursa, to their original settlement places ${ }^{32}$. The important point here is that this group had emigrated from Crete where the Muslim population had been largely Greek speaking (Popoviç 1995: 313-318). Alongside the Albanians, Bosnians, Pomaks and Roma people, the government was cautious in settling the exchangees from Crete. This policy continued to be carried out in the subsequent years. In 1933, for example, an official report ordered the application of the aforementioned Law 675 carefully for the exchangee 'Gypsies' who had left their official settlement areas of Mersin and had gone to İzmir ${ }^{33}$.

[35] Evidently, alongside the necessity of coping with the demographic chaos, an assimilatory goal was also on the agenda of the settlement policies in the early years of the Republic. In practice, however, this could not be realized successfully and the Ministry of Exchange, Reconstruction and Settlement became the target of harsh criticism in the Turkish Grand National Assembly.

\section{The Closing of the Ministry of Exchange, Reconstruction and Settlement}

[36] The problems that appeared in the settlement of exchangees came to be a major subject in the National Assembly. Esat Bey, deputy of Menteşe region, addressed the following questions to the Ministry ${ }^{34}$. How many immigrants and exchangees had come? How many immigrants and exchangees had been settled? How much reconstruction had been made and where?

[37] This interpellation ignited discussions and critiques with respect to the implementation of the settlement policies. Some of the critiques were related to the material difficulties, administrative mistakes and improprieties, which resulted in casualties and material losses not only of the exchangees but also of the other immigrants and the homeless people (Aktar 1997: 32-41) ${ }^{35}$.

[38] Nevertheless, another topic expressed repeatedly by most of the deputies is more notable for the focus of this paper. Alongside these problems, the Ministry was found unsuccessful in settling non-Turkish-speaking immigrants in accordance with the policy of assimilation. One of the

\footnotetext{
32 BCA, Fon No: 272..0.0.12, Yer No: 44.70..8, 11/05/1925.

${ }^{33}$ BCA, Fon No: $272 . .0 .0 .12$, Yer No: $63.190 . .5,07 / 03 / 1933$.

${ }^{34}$ BCA, Fon No: 30..10.0.0, Yer No: 6.38..2, 19/10/1924.

35 For the discussions about these matters in the Parliament, see TBMM Zabıt Ceridesi, Devre: II, Cilt: 9, İçtima: 49, 30/10/1340-30/10/1924, pp. 81-107.
} 
Citation: Ülker, Erol 'Assimilation of the Muslim communities in the first decade of the Turkish Republic (1923-1934) ', European Journal of Turkish Studies, URL: http://www.ejts.org/document822.html

To quote a passage, use paragraph (§).

most important critiques directed at the Ministry was the admission of Albanians as exchangees and their collective settlement in İstanbul and İzmir ${ }^{36}$.

[39] Albanians appeared in the discussions of National Assembly before the interpellation of Esat Bey with another motion submitted by Mehmet Bey, deputy of Çanakkale ${ }^{37}$. This motion asked for information on the relocation of Albanians to the Erenköy district of İstanbul. As it became obvious with the speech of Mustafa Necati, former chief of the Ministry, the Albanian-speaking Muslims of Greece's Yanya region, who had immigrated to Turkey due to the population exchange, came to be the center of this dispute ${ }^{38}$. Nevertheless, the critics were not confined to Albanian speakers. Hamdullah Suphi's speech clarified that what was perceived as a problem was not only the settlement of Albanians in a 'wrong' way but also the broader failure of the Ministry to apply the assimilatory principles of settlement provided by the aforementioned official regulations.

'They settled the Greek-speaking people around İstanbul. This is a gross error. They settled the incomers of Yanya from Gekbuze towards here. Some of them were settled in Çatalca and its surrounding. However, if there is a language different from Turkish in the areas inhabited by the overwhelming Turkish majority, we must isolate it (Applauds). They settled the Greek speaking masses right across the sea from the islands. A grave mistake! Soon, when peace truly reigns and if relations between the islands and our shores pick up and the Greek islanders and Greek-speaking masses reestablish contact, then it will be impossible to eradicate this language, ${ }^{\prime 39}$.

[40] Ali Şuri Bey, the deputy of Karesi, directed similar criticism to the implementation of settlement policies.

'The Zeytinler village of Edremit consists of 568 dwellings and out of these dwellings, 200 are native people (ahali-i kadime), 200 are Bulgarian-speaking Pomak Turks, and an undetermined number of people was speaking Albanian and Bosnian languages. Among the people inhabited on the coast, the dominant dance is Polka instead of our national dance; the dominant musical instruments are the mandolin and the bagpipe instead of our national

\footnotetext{
${ }^{36}$ Rıza Nur was at the forefront of these critiques TBMM Zabıt Ceridesi, Devre: II, Cilt: 9, İçtima: 49, 30/10/134030/10/1924, pp. 84-87.

${ }^{37}$ BCA, Fon No: 30..10.0.0, Yer No: 6.33..18, 05/12/1923.

38 TBMM Zabıt Ceridesi, Devre: II, Cilt: 10, İçtima: 2, 05/11/1340-05/11/1924, p. 62.

39 TBMM Zabıt Ceridesi, Devre: II, Cilt: 9, İçtima: 49, 30/10/1340-30/10/1924, p. 92.
} 
Citation: Ülker, Erol 'Assimilation of the Muslim communities in the first decade of the Turkish Republic (1923-1934) ', European Journal of Turkish Studies, URL: http://www.ejts.org/document822.html

To quote a passage, use paragraph (§).

instruments; the dominant languages are Albanian and Bosnian instead of our national language. Is this, too, a question of appropriations? ${ }^{40}$

[41] Apparently, the gathering of the non-Turkish-speaking immigrants in a region was one of the most import themes of the critics. Such critiques did not only target the Albanian-speakers but also Bosnians, Roma people, Pomaks, Circassians and immigrants from Crete. Riza Nur, for example, sharply criticized the Ministry for inappropriate settlement of the Circassians and immigrants from Crete and the Albanians as well as Bosnians ${ }^{41}$. Approximately one month after this parliamentary debate, on December 11, 1924, the Ministry of Exchange, Reconstruction and Settlement was closed and its duties were delegated to the Department of Settlement created under the Ministry of Interior ${ }^{42}$.

\section{Law on Settlement adopted in 1926}

[42] After the closure of Ministry of Settlement, the government engaged in a more systematic policy of social-engineering, as the adoption of numerous legislations with respect to settlement and re-settlement demonstrates. Their primary objective was clarified by Besim Atalay's speech in the Turkish Grand National Assembly, in which he called for the preparation of a regulation designed for the Turkification of non-Turkish-speaking elements.

'At what time will we make Turkish the language of the people we call Turk? I wonder, why we do not compel, why we do not oppress. Why do the Albanians who have come here speak Albanian? Why does Bosniak speak Bosniak and Circassian speaks Circassian?'43

[43] On May 31, 1926, shortly after Atalay's speech, the Law on Settlement (Law 885) was adopted. It was one of the most important pieces of legislations of the 1920s, designed in accordance with the mentality of social engineering ${ }^{44}$.This law included significant stipulations for the settlement not only of immigrants but also of nomadic tribes, and the Roma population of Turkish nationality as

\footnotetext{
40 TBMM Zabıt Ceridesi, Devre: II, Cilt: 10, İçtima: 2, 05/11/1340-05/11/1924, p. 28.

41 TBMM Zabıt Ceridesi, Devre: II, Cilt: 10, İçtima: 4, 05/11/1340-05/11/1924, p.152.

42 'Mübadele İmar ve İskan Vekaletinin Lağvile Vazifesinin Dahiliye Vekaletine Devri Hakkında Kanun', no: 529, 11/12/1340-11/12/1924, Düstur, Tertip: 3, Cilt: 6, pp. 37-38.

43 TBMM Zabıt Ceridesi, Devre: II, Cilt: 23, İçtima: 74, 20/03/1926, p.271.

44 'İskan Kanunu', no: 885, 31/06/1926, Düstur, Tertip: 3, Cilt: 7, pp. 1441-1443.
} 
Citation: Ülker, Erol 'Assimilation of the Muslim communities in the first decade of the Turkish Republic (1923-1934) ', European Journal of Turkish Studies, URL: http://www.ejts.org/document822.html

To quote a passage, use paragraph (§).

well. Article 1 leaves the decisions about settlement regions of the immigrants, who came to Turkey individually or collectively, to the initiative of the Ministry of Interior. Nevertheless, according to Article 3 , the settlement of the nomadic individuals and tribes is left to the decision of the Council of Ministers, which is to be implemented by the Ministry of Interior. There is also an important provision for the Roma people. According to Article 5, whereas the 'Gypsies' of Turkish nationality ought to be settled in an 'appropriate' region, foreign 'Gypsies' are to be expelled from the country.

[44] Up to 1934, when a new and more extensive law on settlement was adopted, this law continued to be used as one of the important instruments of the Republic's homogenization policies. During this period, the Ministry of Interior took caution in settling the immigrants in accordance with the goal of nationalization. For this reason, the Ministry tried to learn the linguistic and ethnic composition of the provinces to designate the appropriate places for the relocation of refugees. $A$ report from the Ayaş district, for example, informed the Ministry of Interior about the numbers of Turkish, 'Gypsy' and Bosnian immigrants together with the numbers of Muslims from Bulgaria and Romania $^{45}$. This is a very detailed report including a table with information about nationality on a street-by-street level. For instance, 48 Bosnians inhabited İhsaniye Street, making them $100 \%$ of the population there. In Hacı Recep Street, on the other hand, 422 Turks constituted $99.2 \%$ of the population. There were also 6 Muslim 'Gypsies' in another street of Ayaş. A similar report from Düzce province provided the names and the populations of the villages that had been inhabited by the 'nonTurkish elements ${ }^{46}$.

[45] Aside from the immigrants, the government located nomad people and tribes by means of the Article 3 of Law 885. It carefully distinguished the Turkish and non-Turkish-speaking nomads. With a governmental decree and the approval of the Council of Ministers, for example, a nomadic tribe composed of 150 'Turk' people were transferred from the Aksaray region to the Amarat village and settled there together ${ }^{47}$. Similarly, 279 nomad individuals of 'Turkish race' from the various villages of the Sorgun district were settled together in the Çat village ${ }^{48}$. However, another governmental decree dealt differently with a nomadic tribe from Artvin province, whose members

\footnotetext{
45 BCA, Fon No: 272..0.0.65, Yer No: 6.5..6, 10/05/1927.

${ }^{46}$ BCA, Fon No: 272..0.0.12, Yer No: 59.161..6, 18/06/1928.

${ }^{47}$ BCA, Fon No: 30..18.1.2, Yer No: 26.12..15, 02/03/1932.

${ }^{48}$ BCA, Fon No: 30..18.1.2, Yer No: 40.78..8, 05/11/1933.
} 
Citation: Ülker, Erol 'Assimilation of the Muslim communities in the first decade of the Turkish Republic (1923-1934) ', European Journal of Turkish Studies, URL: http://www.ejts.org/document822.html

To quote a passage, use paragraph (§).

were called 'Hemşinli'49 . Indeed, the term Hemşinli used in this decree addressed a Muslim community speaking Armenian as mother tongue ${ }^{50}$. Similar to the general way of treating the nonTurkish-speaker immigrants, this decree ordered the transfer of the Hemşinli nomads to the interior regions. Furthermore, it did not specify any settlement place and rather demanded their transfer to the interior 'provinces'. This meant that the Hemşinlis would be scattered to different regions.

[46] As to the Roma population, an instruction sent to the Mersin province by the Ministry of Interior makes the meaning of the term 'appropriate region' (Article 5 of Law 885) quite clear ${ }^{51}$. This decree was about 146 exchangee 'Gypsies' who had fled from Mersin to İzmir without official permission. They had been brought back to Mersin in accordance with the aforementioned law 675 making obligatory for the settled people not to change the original settlement places. Upon the question of the local authority of Mersin about how to re-settle these 'Gypsies', the Ministry of Interior ordered the settlement of each 'Gypsy' dwelling to the different villages of the province.

\section{Turkification of Eastern Provinces}

[47] The Kurdish population who inhabited the Eastern Provinces and who repeatedly revolted against the Republic became another target of assimilation policies starting with 1925. By the establishment of the Turkish Republic, Kurds had constituted approximately $20 \%$ of the population (Zürcher 1999: 249). They were disappointed by the official ideology of the Republic viewing the Turkish population as the legitimate owner of the country, and by the lack of any reference in Lausanne Conference and in the constitution of the new state to their rights and identity. The Kurdish opposition became a serious problem for the government with the Şeyh Sait (1925), Ağrı (1927-30), and Dersim (1936-38) revolts during the interwar period (Bozarslan 2002: 848). Facing such an active opposition, from the second half of the 1920s on, the Republic embarked upon the Turkification of the Eastern Provinces. This had two dimensions that were highly similar to the general pattern of settlement policies. While the rebellious Kurds were deported to the western parts of the country, the government intended to colonize the Eastern Provinces with the Turkish immigrants of the Caucasian and, especially, Balkan origins.

${ }^{49}$ BCA, Fon No: 30..18.1.2, Yer No: 40.78..2, 05/11/1933.

50 There are also Turkish-speaker Hemşinlis. But the Hemşinli groups inhabited in Artvin region were overwhelmingly Armenian-speakers. For general information on Hemşinlis, see Andrews and Benninghaus (1989: 130, 358-359).

51 BCA, Fon No: 272..00.12, Yer No: 63.190..5, 07/03/1933. 
Citation: Ülker, Erol 'Assimilation of the Muslim communities in the first decade of the Turkish Republic (1923-1934) ', European Journal of Turkish Studies, URL: http://www.ejts.org/document822.html

To quote a passage, use paragraph (§).

[48] Upon the outbreak of Ağrı uprising, the deportation of recalcitrant Kurds was regulated by the 'Law concerning the Relocation of Some Individuals from the Eastern Zone to the Western Provinces $^{, 52}$. It ordered the transfer of up to 1400 peoples and 80 dwellings from the zone of martial law - which had been announced by the time the Şeyh Sait revolt erupted in 1925 - and Bayazit Province the Western Provinces. In another incident, the government relocated 41 people with 10 dwellings from Bitlis to the western part of the country (Çağaptay 2002a: 228).

[49] The policy of deportation was carried further even after the repression of the Ağrı revolt. In November 1931, for example, in accordance with the government's decision to relocate some of the tribes on the Iraq frontier to the Western Provinces, a group of 300 families arrived at İstanbul and it was announced by the Turkish Press that they would be settled in Tekirdag ${ }^{53}$. Moreover, 122 people belonging to the Halikanlı tribe, one of the recalcitrant tribes, arrived at İzmir via Trabzon and İstanbul in the same month ${ }^{54}$. At the beginning of 1932, the Turkish Press announced that the forced relocation of the Halikanlı tribe from eastern to western Turkey was completed. These tribesmen had been settled in Thrace and had already begun to cultivate the lands provided for them by the time this news item was published ${ }^{55}$.

[50] Another way of dealing with the disobedient Kurds was to change their settlement places without sending them to the western regions of the country. For this purpose, the Council of Ministers issued two important decrees in 1930 and in $1931^{56}$. They regulated the relocation of the Kurds inhabiting the mountainous areas of Dersim to the Elazı ğ plain. The reason underlying this decision was to transfer the unreliable elements from the places that were hard to control to the areas that were easier to exercise authority upon.

[51] Besides the policy of deportation, the government resorted to the settlement of immigrants to the Eastern Provinces in order to Turkify the region. In June 1927, for example, the

\footnotetext{
52 'Bazi Eşhasin Şark Menatıkından Garp Vilayetlerine Nakillerine Dair Kanun', no: 1097, 10/06/1927 in Eski ve Yeni Toprak, İskan Hükümleri ve Uygulama Klavuzu, pp. 28-30.

53 Records of the Department of State Relating to the Internal Affairs of Turkey 1930-1944 (M 1224), Review of the Turkish Press for the period 12 November-55 November 1931, 897.9111/337.

54 Records of the Department of State Relating to the Internal Affairs of Turkey 1930-1944 (M 1224), Review of the Turkish Press for the period 15 November-30 November 1931, 897.9111/340.

55 Records of the Department of State Relating to the Internal Affairs of Turkey 1930-1944 (M 1224), Review of the Turkish Press for the period January 24-February 6 1932, 897.9111/348.

56 'Elazığ Ovasında Yerleştirilen Dersimliler Hakkında', no: 8734, 01/01/1930; 'Dağlık Mıntıkalarda Yaşayan Halkın İskanı', no: 10822, 18/3/1931 in Eski ve Yeni Toprak, İskan Hükümleri ve Uygulama Klavuzu, pp. 165-166.
} 
Citation: Ülker, Erol 'Assimilation of the Muslim communities in the first decade of the Turkish Republic (1923-1934) ', European Journal of Turkish Studies, URL: http://www.ejts.org/document822.html

To quote a passage, use paragraph (§).

Turkish Press published news about this issue ${ }^{57}$. According to the information attributed to the Department of Settlement, the number of immigrants, including those from the Caucasus, who were going to be settled in the Eastern Provinces during that year, was between 40,000 and 50,000.

[52] Indeed, Ankara had prepared the ground for the settlement of immigrants in the eastern part of the country even before that date. A report, which was sent from the Muş Province to the Ministry of Interior after the repression of the Şeyh Said uprising, illustrates the intention of the government. It was a very detailed report providing information over the housing and settlement conditions of the Bolanik and Malazgirt fields where the expected immigrants would be placed. After giving wide-ranging information from the number of the abandoned properties to the fields of grassland, this report stated the possibility of locating important number of immigrants to these fields ${ }^{58}$. Upon this, some of the immigrants, who came from Yugoslavia, were placed in Diyarbakır as early as $1925^{59}$.

[53] In the early 1930s, the strategy of placing the immigrants in the Kurdish-populated regions was still an important dimension of the settlement policy. The Cumhuriyet newspaper announced on October 23, 1933, that about 100,000 immigrants would be settled in the eastern provinces and some of them arrived at Muş Province ${ }^{60}$. In the following days, several news items appeared in the Turkish Press on this issue. On November 22, for example, Milliyet published news about immigrants from Romania who would be settled in the eastern provinces ${ }^{61}$. Similar news announced that 511 immigrants from Romania were transferred to Elazl $\breve{g}^{62}$. Nevertheless, the government was careful in preventing the transfer of non-Turkish-speakers to east. For example, the settlement place provided to 200 Pomak migrants from Bulgaria was Yozgat, the province of Interior Anatolia ${ }^{63}$.

[54] Furthermore, the government promoted the Turkification of the Eastern Provinces through the adoption of particular laws. The 'Law concerning Land Distribution within the Eastern

\footnotetext{
${ }^{57}$ Records of the Department of State Relating to the Internal Affairs of Turkey 1910-1929 (M 353), Review of the Turkish Press for the period 1 June-18 June 1927, 897.9111/189.

${ }^{58}$ BCA, Fon No: 272..0.0.12, Yer No: 45.77..5, 16/08/1925

${ }^{59}$ BCA, Fon No: 272..0.0.12, Yer No: 45.75..3, 06/07/1925

60 'Altınova'ya 100 Bin Muhacir İskan Edilecek', Cumhuriyet, 23 October 1933, p. 3.

61 'Romanya'lı Muhacirler Bugün Geliyor', Milliyet, 22 November 1933, p. 3.

62 'Romanya'dan Gelen Irkdaşlarımız Elaziz'e Gönderildi: Muhaceretin Muntazam Kafileler Halinde Taakup Edeceği Söyleniyor', Milliyet, 24 November 1933, p. 1.

63 'Bulgaristandan Kaçan Pomaklar', Cumhuriyet, 5 April 1934, p. 5.
} 
Citation: Ülker, Erol 'Assimilation of the Muslim communities in the first decade of the Turkish Republic (1923-1934) ', European Journal of Turkish Studies, URL: http://www.ejts.org/document822.html

To quote a passage, use paragraph (§).

Zone to the Needy Farmers' (May 2, 1929) served this purpose ${ }^{64}$. It gave the government the juridical right of distributing lands of public treasury in the Eastern Provinces to immigrants alongside the poor farmers, nomads and tribesmen. More importantly, on May 9, 1934, shortly before the promulgation of Law on Settlement of 1934, the Turkish Grand National Assembly adopted another law. It regulated the distribution of the lands and properties that belonged to the public treasury and that remained from the repatriated emigrants of the Russian nationality to the immigrants and refugees ${ }^{65}$. In particular, it was about Kars, Bayazit, Erzurum and Çoruh provinces within which Ankara wanted to increase Turkish population. Both of these laws, in fact, were used to promote the migration of Turkish-speaking people to the eastern regions by providing the newcomers with material benefits.

\section{Concluding Remarks}

[55] According to figures provided by Justin McCarty (1983: 140), the population of Anatolia fell by 30 percent from 1912 to 1922 . The number of Muslims decreased from 13.7 million to 11.2 million between these years of consecutive wars. The number of non-Muslims, on the other hand, decreased dramatically from 2.8 million to 0.3 million in the same period. The turbulent years of wars had gone with massacres, deportations, forced migrations and war time casualties. McCarty estimates that approximately $10 \%$ of the Anatolian population emigrated and $20 \%$ died between 1912 and 1922. Tens of thousands of people had become homeless in the various parts of Anatolia by the time the Republic was constituted (Arı 2000: 8-11). Besides the immigrants from the Balkans and the Caucasus, a significant number of native dwellers, who lost their homes because of the wartime conditions, were to be settled to prevent demographic chaos.

[56] The policies of immigration and settlement had crucial importance for the founders of the Republic in this context. Increasing the population was regarded as an urgent necessity for both economic and social reasons. Thus bringing the Muslims residing outside of the country was seen as a solution to the demographic problems. At the same time, immigrants and homeless people were to be systematically settled and specific measures were to be undertaken to regulate this process.

\footnotetext{
64 'Şark Menatıkı Dahilinde Muhtaç Zürraa Tevzi Edilecek Araziye Dair Kanun', no: 1505, 02/06/1929 in Eski ve Yeni Toprak, İskan Hükümleri ve Uygulama Klavuzu, pp. 34-35.

65 'Kars Vilayetiyle Bayazit, Erzurum ve Çoruh Vilayetlerinin Bazı Parçalarında Muhacir ve Sığıntıların Yerleştirilmesi ve Yerli Çiftçilerin Topraklandırıması Hakkında Kanun', no: 2502, 09/06/1934 In Eski ve Yeni Toprak, İskan Hükümleri ve Uygulama Klavuzu, pp. 400-401.
} 
Citation: Ülker, Erol 'Assimilation of the Muslim communities in the first decade of the Turkish Republic (1923-1934) ', European Journal of Turkish Studies, URL: http://www.ejts.org/document822.html

To quote a passage, use paragraph (§).

[57] However, these concerns constituted only one dimension of the immigration and settlement policies. The founders of the new state aspired for the creation of a nation-state. In their understanding this meant that the new state was to overlap a homogenous nation whose individuals were to be politically loyal Muslims, speaking Turkish and possessing Turkish culture. Nevertheless, besides having been depopulated and disordered, Anatolia was multiethnic and, to some extent, multi-religious. There were still Greeks, Jews and Armenians whose residence in Anatolia the nationalist elite found burdensome. Aside from them, the Muslim majority of the country was hardly homogenous. There were Kurds, Bosnians, Albanians, Circassians and Arabs, who were speaking languages other than Turkish ${ }^{66}$.

[58] In this respect, the demographic devices of settlement and immigration were among the tools available for the government to homogenize the population on the basis of Turkish language and culture since the foundation of the Republic. The extent to which ethnicity and race became the reference points of the assimilation policies in the first decade of the Republic is open to discussion. One can also question whether Turkish nationalism underwent a significant change in the 1930s in terms of the development of more ethnicity-oriented discourse. What is certain is that the ruling elite were attentive to the linguistic, cultural and religious unity of the population and this attentiveness reflected on the immigration-settlement policies. Concerning these policies of nation-building, there was no significant difference between the 1930s and the 20s. In both periods, the state was concerned with religious homogeneity as well as linguistic-cultural assimilation. The nationalist discourse at the state level seems to have evolved into a more essentialist, ethnicist one from the 1920s to the 30s. Nevertheless, this evolution seems to have little effect on the policies of nationbuilding.

${ }^{66}$ For official numbers of non-Turkish-speaking Muslims in the censuses, see Fuat Dündar (1999). 
Citation: Ülker, Erol 'Assimilation of the Muslim communities in the first decade of the Turkish Republic (1923-1934) ', European Journal of Turkish Studies, URL: http://www.ejts.org/document822.html

To quote a passage, use paragraph (§).

\section{References}

Unpublished Resources:

Başbakanlık Cumhuriyet Arşivi (BCA).

The National Archives of the United States:

Records of the Department of State Relating to the Internal Affairs of Turkey 1919-1929 (M 353).

Records of the Department of State Relating to the Internal Affairs of Turkey 1919-1929 (M 353),

Review of the Turkish Press.

Records of the Department of State Relating to the Internal Affairs of Turkey 1930-1944 (M 1224).

Records of the Department of State Relating to the Internal Affairs of Turkey 1930-1944 (M 1224),

Review of the Turkish Press.

Published sources:

Düstür

Eski ve Yeni Toprak, İskan Hükümleri ve Uygulama Klavuzu (1952), edited by Kökdemir, Naci, Ankara.

İskan Tarihçesi, İstanbul, Hamit Matbaası, 1932.

TBMM Gizli Celse Tutanakları

TBMM Zabıt Cerideleri

Periodicals:

Cumhuriyet

Milliyet

Books and articles:

Ağanoğlu, H. Yıldırım (2001) Osmanlı'dan Cumhuriyete Balkanlar'ın Makus Talihi: Göç, İstanbul, Kumsaati Yayınları.

Akçam, Taner (1997) 'Hızla Türkleşiyoruz' in Nuri Bilgin (ed.) Cumhuriyet, Demokrasi ve Kimlik, İstanbul, Bağlam Yayınclık, pp. 143-158.

Aktar, Ayhan (1998) 'Homogenizing the Nation; Turkifying the Economy: Turkish Experience of Populations Exchange Reconsidered', paper presented at the conference on The Exchange of Populations, The Refugee Studies Program, Oxford, Quinn Elizabeth House, September. 
Citation: Ülker, Erol 'Assimilation of the Muslim communities in the first decade of the Turkish Republic (1923-1934) ', European Journal of Turkish Studies, URL: http://www.ejts.org/document822.html

To quote a passage, use paragraph (§).

Aktar, Ayhan (2001) Varlık Vergisi ve Türkleştirme Politikaları, İstanbul, İletişim Yayınları.

Andrews, Peter Alford-Benninghaus, Rüdiger (eds.) (1989) Ethnic Groups in the Republic of Turkey, Wiesbaden, Dr. Ludwig Reichert Verlag.

Arı, Kemal (2000) Büyük Mübadele: Türkiye'ye Zorunlu Göç (1923-1925), İstanbul, Tarih Vakfı Yurt Yayınları.

Bora, Tanıl (1995) 'Türkiye'de Milliyetçilik ve Azınlıklar', Birikim 71-2, March-April, pp. 34-50.

Bozarslan, Hamit (2002) 'Kürd Milliyetçiliği ve Kürd Hareketi, (1898-2000)' in Bora, Tanıl; Gültekingil, Murat (eds.) Modern Türkiye'de Siyasi Düşünce: Milliyetçilik, İstanbul, İletişim Yayınları, vol. 4, pp. 841-870.

Çağaptay, Soner (2002a) 'Kemalist Dönem'de Göç ve İskan Politikaları: Türk Kimliği Üzerine Bir Çalışma', Toplum-Bilim 93 (Summer), pp. 218-241.

Çağaptay, Soner (2002b) 'Otuzlarda Türk Milliyetçiliğinde Irk, Dil ve Etnisite' in Bora, Tanıl ; Gültekingil, Murat (eds.) Modern Türkiye'de Siyasi Düşünce: Milliyetçilik, İstanbul, İletişim Yayınları, vol. 4, pp. 245-249.

Çağaptay, Soner (2004c) 'Race, Assimilation and Kemalism: Turkish Nationalism and the Minorities in the 1930s', Middle Eastern Studies 40 (3), May, pp. 86-101.

Dündar, Fuat (1999) Türkiye Nüfus Sayımlarında Azınlıklar, İstanbul, Doz Yayınları.

Eren, Halit (1993) 'Balkanlarda Türk ve Diğer Müslüman Toplumları ve Göç Olgusu', Ortadoğu ve Balkan Incelemeleri Vakfı (OBIV) Yayınları, pp. 289-299.

Geray, Cevat (1962) Türkiye'den ve Türkiye'ye Göçler ve Göçmenlerin İskanı, Ankara, Siyasal Bilgiler Fakültesi-Maliye Enstitüsü.

Kazgan, Gülten (1983) 'Milli Türk Devletinin Kuruluşu ve Göçler', Cumhuriyet Dönemi Türkiye Ansiklopedisi, vol. 6, Nüfus, İstanbul, İletişim Yayınları, pp. 1556-1563.

Kirişçi, Kemal (2000) 'Disaggregating Turkish Citizenship and Immigration Practices', Middle Eastern Studies 36 (3), July, pp. 1-22.

Ladas, Stephen P. (1932) The Balkan Exchange of Minorities: Bulgaria, Greece and Turkey, New York, MacMillan.

McCarty, Justin (1983) 'Foundations of the Turkish Republic: Social and Economic Change', Middle Eastern Studies 19 (2), April, pp. 139-151.

McCarty, Justin (1998) Ölüm ve Sürgün: Osmanlı Müslümanlarına Karşı Yürütülen Ulus Olarak Temizleme İşlemi, İstanbul, İnkılap Kitabevi Yayın San ve Tic. A. Ş. 
Citation: Ülker, Erol 'Assimilation of the Muslim communities in the first decade of the Turkish Republic (1923-1934) ', European Journal of Turkish Studies, URL: http://www.ejts.org/document822.html

To quote a passage, use paragraph (§).

Popoviç, Alexandre (1995) Balkanlar'da İslam, İstanbul, İnsan Yayınları.

Toprak, Zafer (1998) 'The Demographic Consequences of Lausanne Treaty in Turkey' paper presented at the conference on The Exchange of Populations, The Refugee Studies Program, Oxford, Quinn Elizabeth House, September.

Ülker, Erol (2005) 'Contextualising 'Turkification': Nation-building in the late Ottoman Empire, 190818', Nations and

Nationalism 11 (4), pp. 613-636.

Yıldız, Ahmet (2001) Ne Mutlu Türküm Diyebilene: Türk Ulusal Kimliğinin Etno-Kültürel Sınırları (1919-1938), İstanbul, İletişim Yayınları.

Zürcher, Erik Jan (1999) Modernleşen Türkiye'nin Tarihi, İstanbul, İletişim Yayınları. 